\title{
Teknik Analisis Validitas Konstruk dan Reliabilitas instrument Test dan Non Test Dengan Software LISREL
}

\author{
Akbar iskandar \\ Teknik informatika, STMIK AKBA, Sulawesi selatan, Indonesia \\ Email : akbar.iskandar06@gmail.com
}

\begin{abstract}
Abstrak
Tujuan dari tulisan ini adalah untuk menganalisis tingkat kualitas butir instrument tes dan non tes berdasarkan tingkat validitas konstruk dan reliabilitas. Jenis penelitian ini masuk dalam kategori pengembangan instrument yang biasa disebut dengan R \& D. Penelitian ini merupakan bentuk simulasi terhadap instrument yang telah dikembangkan sebelumnya yaitu tahun 2016 dan 2017 yang berjalan selama 4 bulan. Teknik analisis data yang digunakan adalah teknik analisis kuantitatif dimana yang dimaksud adalah Confirmatory Faktor Analisys (CFA) dengan bantuan software LISREL. Hasil analisis dalam simulasi ini ditemukan bahwa butir instrument yang dikembangkan memenuhi criteria valid secara konstruk dan reliabel baik untuk instrument tes maupun non tes.
\end{abstract}

Kata kunci: lisrel, amos, SEM, instrument, tes, non tes, pengukuran, penilaian, evaluasi, spss

Abstract

The purpose of this paper is to analyze the level of grain quality of test and non test instruments based on the level of construct validity and reliability. This type of research belongs to the category of instrument development commonly referred to as $R \& D$. This research is a form of simulation of the instrument that has been developed previously ie 2016 and 2017 which runs for 4 months. Data analysis technique used is quantitative analysis technique which is Confirmatory Factor Analysis (CFA) with the help of LISREL software. The results of the analysis in this simulation found that the developed instrument items meet the criteria valid construct and reliability for instrument test and non test instruments.

Keywords: lisrel, amos, SEM, instrument, test, non test, measurement, assessment, evaluation, spss 


\section{Pengantar validitas dan Reliabilitas}

Sistem pembelajaran adalah keseluruhan komponen pembelajaran yang saling terkait secara terpadu untuk mencapai tujuan pembelajaran yang diinginkan (Iskandar, 2011). Dimana salah satu kunci untuk mengukur keberhasilan pembelajaran adalah instrument yang baik. Sebuah instrument tes maupun non test dikatakan baik atau berkualitas jika instrument tersebut telah memenuhi criteria validitas dan reliable. Dimana Validitas sering diartikan dengan kesahihan atau ketepatan sebuah alat ukur dalam mengukur objek. Sedangkan Validitas konstruk merupakan Validitas yang mengacu pada sejauh mana suatu instrumen tes maupun non tes yang dapat mengukur yang hendak diukur berdasarkan konstruksi teori yang dapat dijadikan sebagai dasar dalam penyusunan instrumen. Selain itu Validitas juga dapat didefinisikan sebagai salah satu bentuk usaha untuk mengukur seberapa jauh item-item mampu mengukur apa yang benarbenar hendak diukur sesuai dengan konsep yang telah ditetapkan sebelumnya. Kriteria valid dalam analisis CFA atau dapat dikatakan valid jika loading factor $>0.30$. Hal ini juga diungkapkan oleh Hair (2010) berdasarkan jumlah sampel seperti Tabel 1:

Tabel 1

Kriteria valid

\begin{tabular}{|c|c|}
\hline Factor Loading & Jumlah Sampel \\
\hline 0.30 & 350 \\
\hline 0.35 & 250 \\
\hline 0.40 & 200 \\
\hline 0.45 & 150 \\
\hline 0.50 & 120 \\
\hline 0.55 & 100 \\
\hline 0.60 & 85 \\
\hline 0.65 & 70 \\
\hline 0.70 & 60 \\
\hline 0.75 & 50 \\
\hline
\end{tabular}

Reliabilitas sering disebut sebagai keandalan dan kemantapan sebuah perangkat tes yakni sejauh mana instrumen tes dapat menghasilkan skor hasil penilaian yang konsisten danstabil. selain itu reliabilitas juga dapat diartikan sebagai bentuk kekonsistenan, keandalan, terpercaya dan keajegan dalam setiap pengujian atau pengukuran sebuah objek baik dilakukan secara internal maupun secara eksternal. Kriteria relibilitas yaitu 0.75 atau Rentang skor reliabilitas bergerak dari 0-1, jika mendekati 1 (satu) maka semakin reliabel sebuah instrument. 


\section{CONTOH 1:}

Hasil Analisis Validitas Konstruk Pada Instrument Non Tes Tanpa Indikator

- Tampilan Diagram Lintasan Model Kepribadian (Standardized Solution)

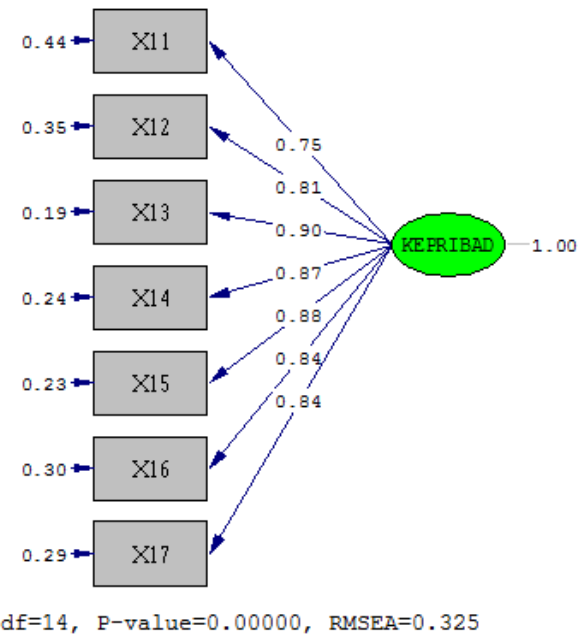

Gambar 1.1 Standardized Solution untuk uji CFA Variabel kepribadiaan - Tampilan Signifikansi Jalur (uji t)

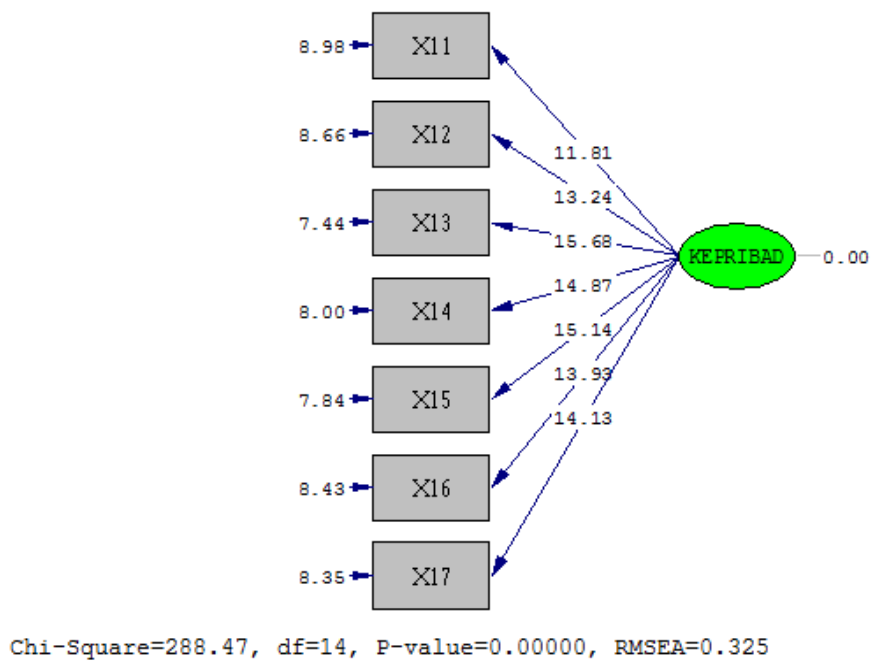

Gambar 1.2 T-Values untuk uji CFA Variabel kepribadiaan

Sebelum melangkah pada penjelasan selanjutnya, Maka perlu terlebih dahulu dijelaskan tentang uji model yang dihasilkan dalam analisis CFA ini. Berdasarkan hasil analisis tersebut tampak bahwa model secara teoritis belum sesuai dengan data empiris (Model belum fit), karena sebagian besar criteria yang digunakan belum memenuhi syarat seperti nilai RMSEA $=0.32>$ $0.08, \mathrm{CFI}=0.87<0.90, \mathrm{NFI}=0.86<0.90, \mathrm{IFI}=0.87<0.9$ (tidak fit), serta masih banyak yang lainnya. Ouput hasil analisis dapat dilihat seperti berikut: 


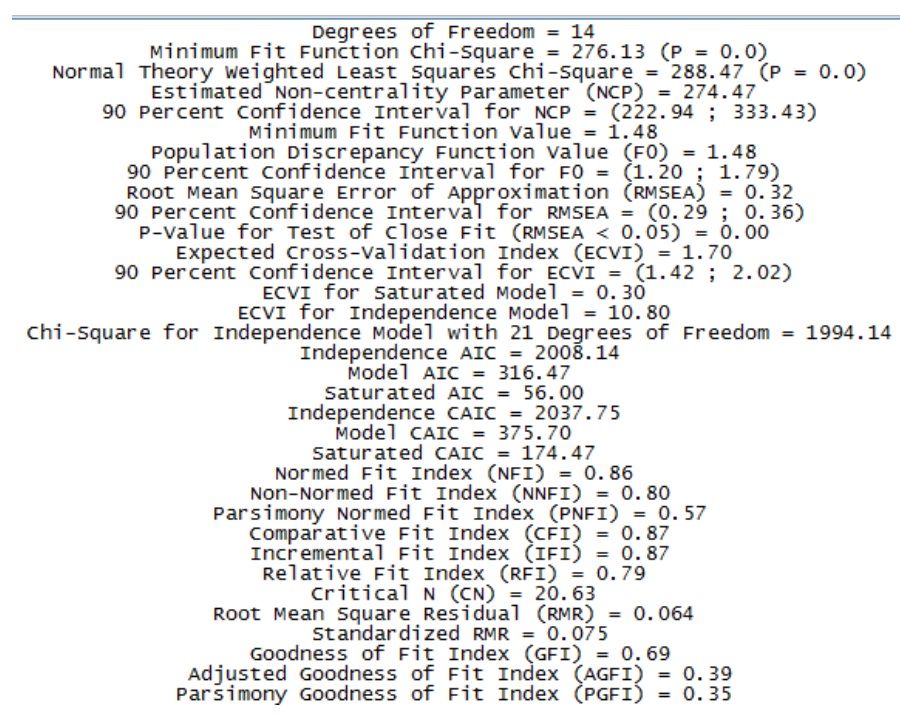

Berdasarkan hasil analisis di atas terlihat bahwa nilai RMSEA dan IFI belum memenuhi criteria fit dan nilai Chi-square masih besar sehingga software lisrel dalam hasil analisis memberikan saran untuk dilakukan modifikasi (The Modification Indices Suggest to Add an Error Covariance). Sehingga hasil analisis yang kedua dapat dilihat seperti berikut:

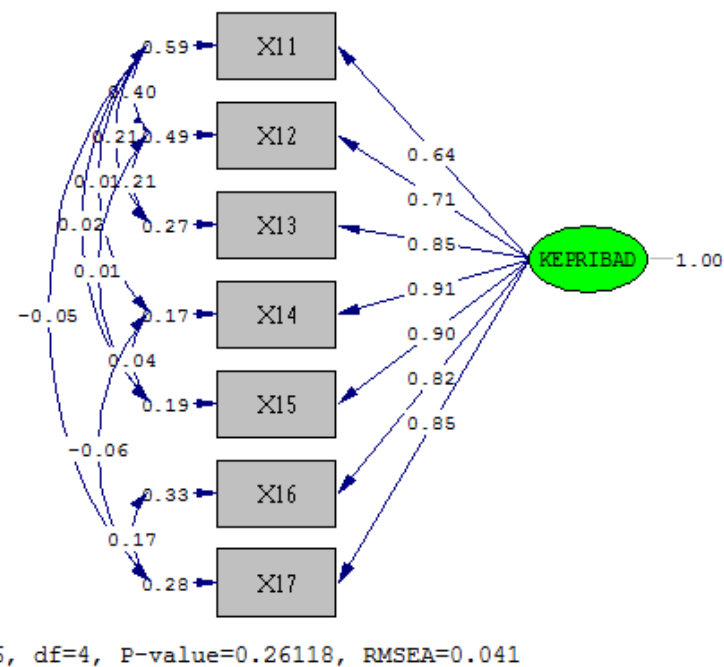

Gambar 1.1 Hasil analisis kedua Standardized Solution CFA Variabel kepribadiaan 


\section{- Tampilan Signifikansi Jalur (uji t)}

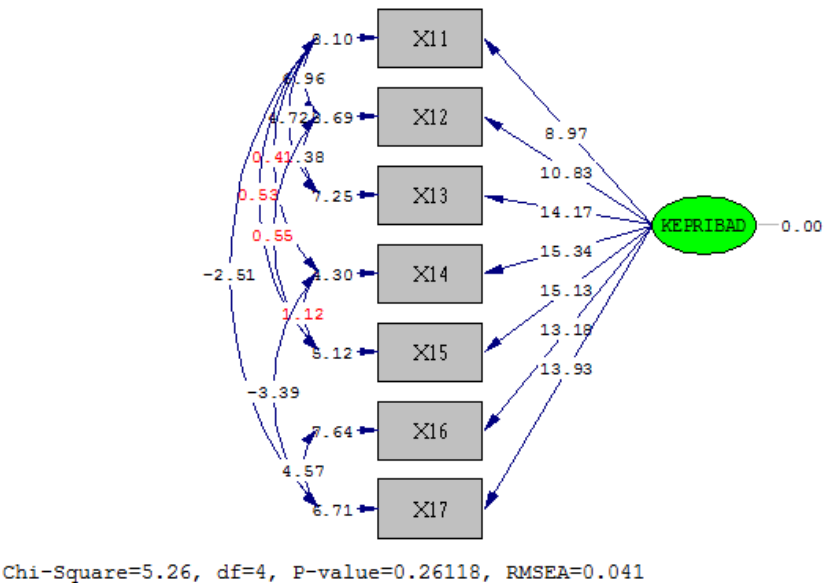

\section{Gambar 1.2 Hasil analisis kedua T-Values CFA}

Variabel kepribadiaan

\section{INTERPRETASI}

\section{Evaluasi Goodness of Fit}

Model secara teoritis sesuai dengan data empiris. Criteria minimal untuk menguji Goodness of Fit model yaitu RMSEA, CFI, NFI, IFI dan PNFI Seperti yang disajikan pada Tabel 1.1.

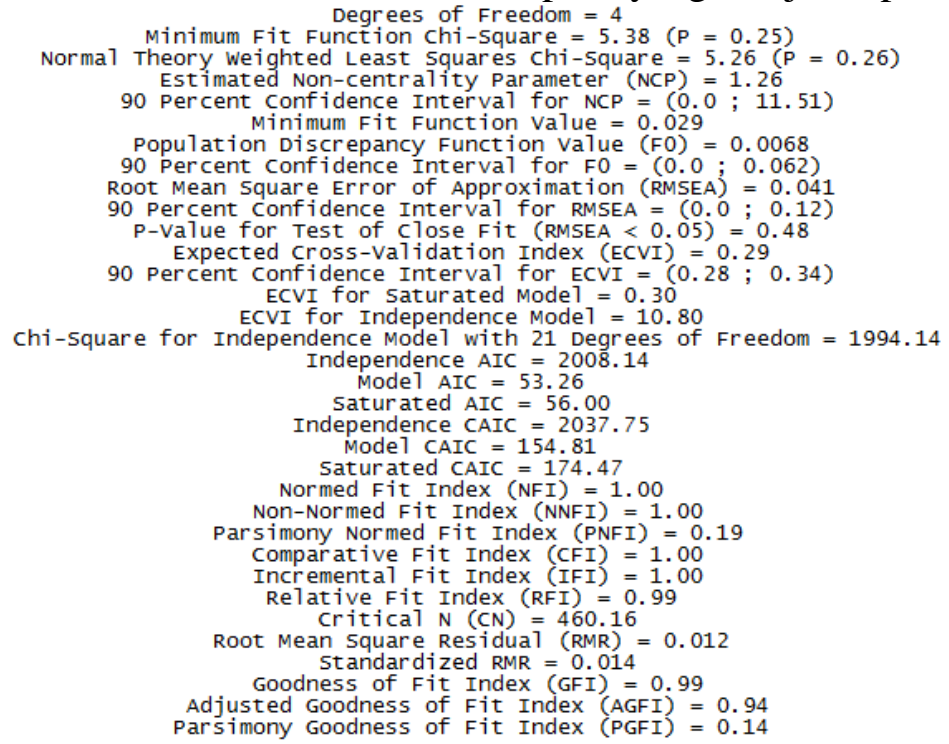




\section{Confirmatory Factor Analysis}

Tabel 1.1. statistic dan criteria fit model

\begin{tabular}{|c|c|c|c|c|}
\hline No. & Statistik & Hasil perhitungan & Kriteria 'fit” & Keterangan \\
\hline & p- value & 0.26 & $>0.05$ & fit \\
\hline 1 & RMSEA & 0.04 & $<0.08$ & fit \\
\hline 2 & CFI & 1.00 & $>0,9$ & fit \\
\hline 3 & IFI & 1.00 & $\geq 0,9$ & fit \\
\hline 4 & NFI & 1.00 & $>0.90$ & fit \\
\hline 5 & PNFI & 0.19 & 0: tidak fit, semakin besar semakin fit & fit \\
\hline
\end{tabular}

Berdasarkan hasil analisis data diperoleh bahwa nilai statistic dan criteria fit model memenuhi criteria model teoritis sesuai dengan data empiric. Oleh karena model teoritis sesuai dengan data empiric, maka pemeriksaan validitas dan reliabilitas dapat dilakukan, untuk keperluan tersebut perhatikan Gambar 1.1 dalam bentuk standardize solution.

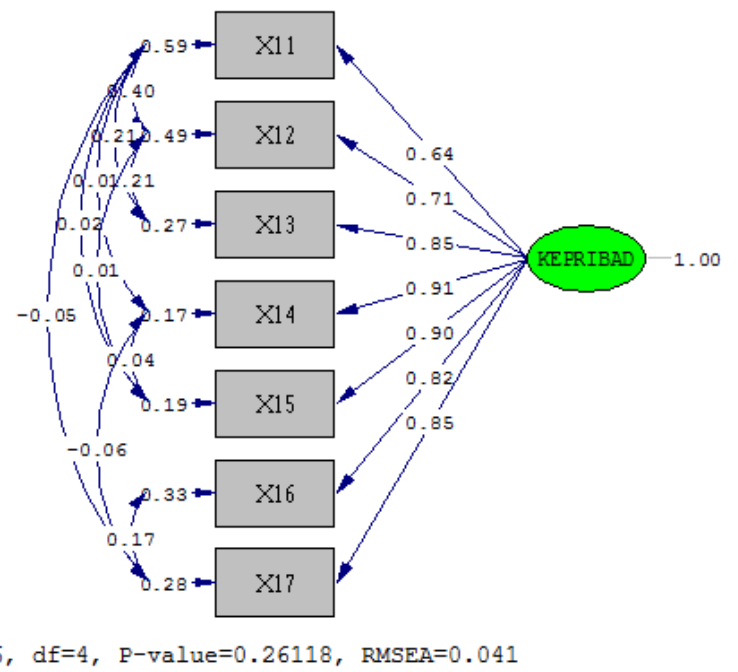

Gambar 1.1 Standardized Solution untuk uji CFA

Mencermati informasi yang disajikan pada gambar 1.1. tampak bahwa factor loading lebih besar dari 0,45 untuk setiap butir instrument yang membangun variable kepribadian. Dengan demikian semua butir memiliki criteria valid karena memiliki loading factor lebih besar dari 0,45. Kemudian tahapan berikutnya adalah menghitung reliabilitas instrument dengan menggunakan rumus (persamaan 4.1) yang dikemukakan oleh solimun (2002:82); Geldhof, Preacher, dan Zyphur (2013:73):

$$
C R=\frac{\left(\sum_{i=1}^{n} \lambda_{i}\right)^{2}}{\left(\sum_{i=1}^{n} \lambda_{i}\right)^{2}+\left(\sum_{i=1}^{n} \delta_{i}\right)}
$$

Keterangan:

$\mathrm{Cr}=$ Koofisien Reliabilitas

$\lambda_{\mathrm{i}}=$ Loading Factor untuk setiap i yang membangun indicator

$\delta_{\mathrm{i}}=$ Standard error untuk butir ke i

Berdasarkan hasil analisis seperti yang disajikan pada gambar 1.1 di atas dan untuk mempermudah perhitungan reliabilitas maka disajikan kembali data seperti pada Tabel 1.2. mencermati informasi yang disajikan pada Tabel 1.2 tersebut, maka nilai koofisien reliabilitas 
dihitung dengan menggunakan rumus persamaan 4.1 yaitu $\mathrm{CR}=0,93$. Nilai CR ini lebih besar dari nilai batas yang digunakan sebagai criteria yaitu 0,7 Lin, 1989 (Mansyur, 2009).

Tabel 1.2 Hasil perhitungan Reliabilitas Instrument kepribadiaan

\begin{tabular}{|l|l|l|l|l|l|l|l|l|l|}
\hline No & b1 & b2 & b3 & b4 & b5 & b6 & b7 & sum & $\wedge 2$ \\
\hline$\lambda$ & 0.64 & 0.71 & 0.85 & 0.91 & 0.90 & 0.82 & 0.85 & 5.68 & 32.2624 \\
\hline$\delta$ & 0.59 & 0.49 & 0.27 & 0.17 & 0.19 & 0.33 & 0.28 & 2.32 & \\
\hline
\end{tabular}

Selanjutnya, dilakukan pemeriksaan pengaruh-pengaruh butir terhadap variabel, apakah signifikan atau tidak, Untuk keperluan tersebut perlu diperhatikan output dalam bentuk t-values seperti pada Gambar 1.2.

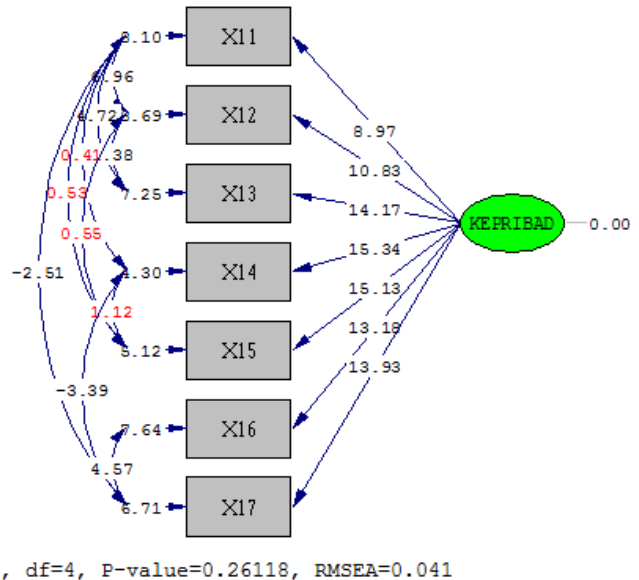

Gambar 1.2 T-Values untuk uji CFA Variabel kepribadian

Merujuk hasil t-values seperti pada gambar 1.2 diatas, tampak bahwa nilai t-hitung untuk masingmasing butir yaitu 8.97; 10.83; 14.17; 15.34 ; 15.13; 13.18; 13.93 berturut-turut. Nilai-nilai tersebut lebih besar dari nilai t-tabel pada taraf signifikansi $\alpha=0,05$ dan derajat bebas 186 (n-1) sebesar 1,97. Hal tersebut menunjukkan bahwa pengaruh masing-masing butir tersebut terhadap kepribadian signifikan. 


\section{CONTOH 2:}

Hasil Analisis Validitas Konstruk Pada Instrument Tes dengan Indikator

- Variabel adalah KB sedangkan yang berfungsi sebagai indikator adalah H-L

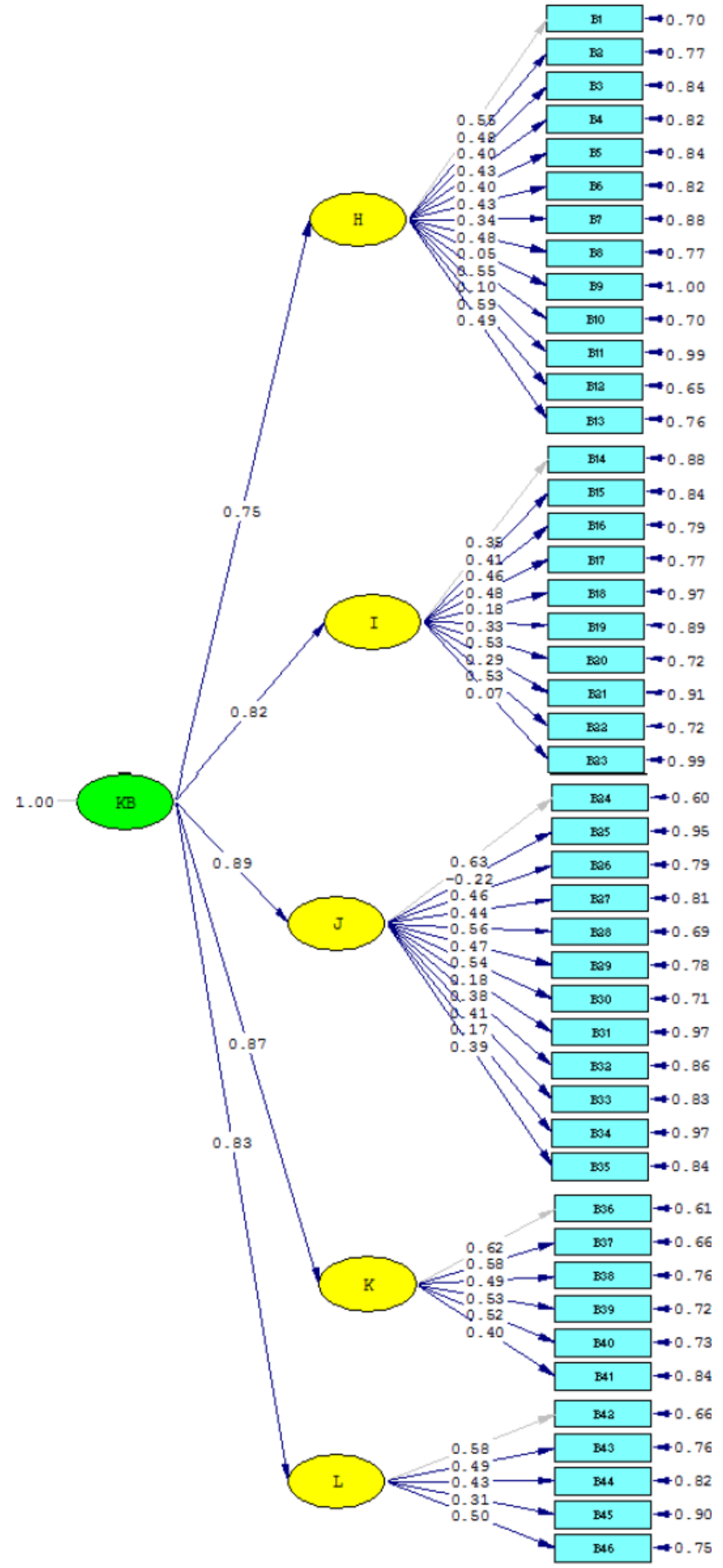

Gambar 2.1. Nilai loading factor masing-masing indikator Analisis tahap I

Mencermati informasi yang disajikan pada Gambar 2.1. tampak bahwa factor loading lebih besar dari 0,3 untuk setiap butir instrument yang membangun indicator $\mathrm{H}$ sampai indikator L. dari indikator tersebut ada 7 butir instrument tdk valid untuk mengukur faktornya yaitu (butir 
9; butir 11;butir 18; butir 23;butir 25; butir 31; butir 34;) SedangkanModel secara teoritis telah sesuai dengan data empiris.Criteria untuk menguji Goodness of Fit model yaitu RMSEA, PNFI dan IFI, Seperti yang disajikan pada Tabel 2.1.

Tabel 2.1.Statistic dan Criteria Fit Model

\begin{tabular}{|c|c|c|c|c|}
\hline No. & Statistik & $\begin{array}{c}\text { Hasil } \\
\text { perhitungan }\end{array}$ & Kriteria 'fit” & Keterangan \\
\hline 1 & $\begin{array}{l}\text { Minimum fit function chi- } \\
\text { square }\left(\chi^{2}\right)\end{array}$ & $\begin{array}{c}3403.83 \\
(\mathrm{P}=0.0)\end{array}$ & $p>0.05$ & Tdk fit \\
\hline 2 & RMSEA & 0.059 & $<0.08$ & Fit \\
\hline 3 & $\begin{array}{l}\text { Root Mean Square Residual } \\
\text { (RMR) }\end{array}$ & 0.043 & $\leq 0,10$ & Fit \\
\hline & Standardized RMR & 0.065 & $\leq 0,10$ & Fit \\
\hline 4 & GFI & 0.83 & $\geq 0,90$ & Tdk fit \\
\hline 5 & AGFI & 0.82 & $0.80 \leq \mathrm{AGFI}<0,9$ & Marjinal fit \\
\hline 6 & NFI & 0.87 & $\geq 0,90$ & Tdk fit \\
\hline 7 & NNFI & 0.90 & $\geq 0,90$ & Fit \\
\hline 8 & CFI & 0.90 & $\geq 0,90$ & Fit \\
\hline 9 & IFI & 0.90 & $\geq 0,90$ & Fit \\
\hline 10 & RFI & 0.86 & $\geq 0,90$ & Tdk fit \\
\hline 11 & PNFI & 0.83 & $\begin{array}{l}\text { 0: tidak fit, semakin besar } \\
\text { semakin fit }\end{array}$ & Fit \\
\hline
\end{tabular}

Diperoleh 8 kriteria yang memenuhi fit dan yang tidak memenuhi (hanya 4) kriteria, sehingga model Fit. Besarnya pengaruh indicator $\mathrm{H}-\mathrm{L}$ dalam membangun variabel $\mathrm{KB}$, maka koefisien gamma dari indicator H-L diperhatikan. Berdasarkan hasil analisis data seperti yang disajikan pada Gambar 2.1 diatas, terlihat bahwa koofisien gamma untuk semua indicator tersebut masing-masing bernilai 0.75 yang berarti sumbangan pengaruh indikator $\mathrm{H}$ sebesar 75\%; Indikator I sebesar 82\% ; Indikator J sebesar 89\%; Indikator K sebesar 87\%; Indikator L sebesar 83\%. Hal tersebut menunjukkan bahwa kelima indicator yang membangun variabel KB memiliki sumbangan atau pengaruh yang signifikan.

Setelah dikeluarkan butir tidak valid yaitu (butir 9; butir 11; butir 18; butir 23; butir 25; butir 31 dan butir 34 karena factor loading < 0.3 (tidak dapat mengukur faktornya) maka selanjutnya dianalisis kembali dan hasil analisis dapat dilihat pada Gambar 2.2. 


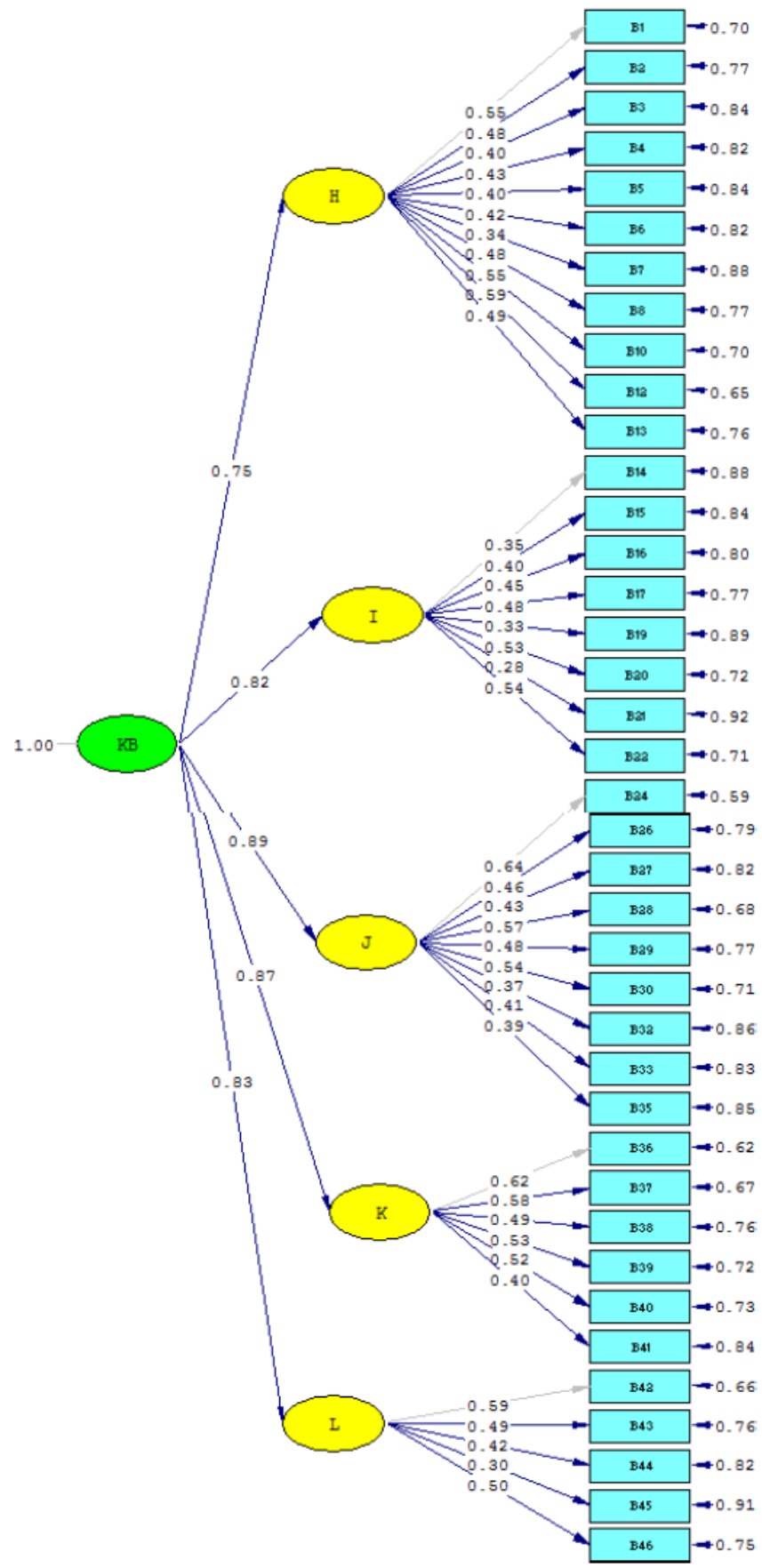

Gambar 2.2Nilai loading factor masing-masing indikator Analisis tahap II

Berdasarkan gambar 2.2. semua butir memenuhi criteria valid untuk mengukur faktornya kecuali butir 21 yang harus direvisi karena memiliki loading factor 0,28 $(0.28<0.3)$. Kemudian tahapan berikutnya adalah menghitung reliabilitas instrument dengan menggunakan rumus (persamaan 4.1) yang dikemukakan oleh Geldhof, Preacher, dan Zyphur (2013:73) dimana hasil analisis CR= 0,92. Nilai CR ini lebih besar dari nilai batas yang digunakan sebagai criteria yaitu 0,7Linn 1989 (Mansyur, 2009:134). 


\section{Confirmatory Factor Analysis}

\begin{tabular}{|c|c|c|c|c|c|c|c|c|c|c|c|c|c|c|c|c|c|c|c|c|c|}
\hline \multicolumn{22}{|c|}{ butir instrument } \\
\hline No & 1 & 2 & 3 & 4 & 5 & 6 & 7 & 8 & 10 & 12 & 13 & 14 & 15 & 16 & 17 & 19 & 20 & 21 & 22 & 24 & 26 \\
\hline$\lambda$ & 0,55 & 0,48 & 0,4 & 0,43 & 0,4 & 0,42 & 0,34 & 0,48 & 0,55 & 0,59 & 0,49 & 0,35 & 0,4 & 0,45 & 0,48 & 0,33 & 0,53 & \begin{tabular}{|l}
0,28 \\
\end{tabular} & 0,54 & 0,64 & 0,46 \\
\hline$\delta$ & 0,7 & 0,77 & 0,84 & 0,82 & 0,84 & 0,82 & 0,88 & 0,87 & 0,7 & 0,65 & 0,76 & 0,88 & 0,84 & 0,8 & 0,77 & 0,89 & \begin{tabular}{|l|l|}
0,72 \\
\end{tabular} & \begin{tabular}{|l}
0,92 \\
\end{tabular} & 0,71 & 0,59 & 0,79 \\
\hline No & 27 & 28 & 29 & 30 & 32 & 33 & 35 & 36 & 37 & 38 & 3 & 40 & 41 & 42 & 43 & 44 & 45 & 46 & Jumlah & Jumla & \\
\hline$\lambda$ & 0,43 & 0,57 & 0,48 & 0,54 & 0,37 & 0,41 & 0,39 & 0,62 & 0,58 & 0,49 & 0,53 & 0,52 & 0,4 & 0,59 & 0,49 & 0,42 & 0,3 & 0,5 & 18,22 & 33 & \\
\hline$\delta$ & 0,82 & 0,68 & 0,77 & 0,71 & 0,86 & 0,83 & 0,85 & 0,62 & 0,67 & 0,76 & 0,72 & 0,73 & 0,84 & 0,66 & 0,76 & 0,82 & 0,91 & 0,75 & 30,32 & & \\
\hline
\end{tabular}

\section{- T-value}

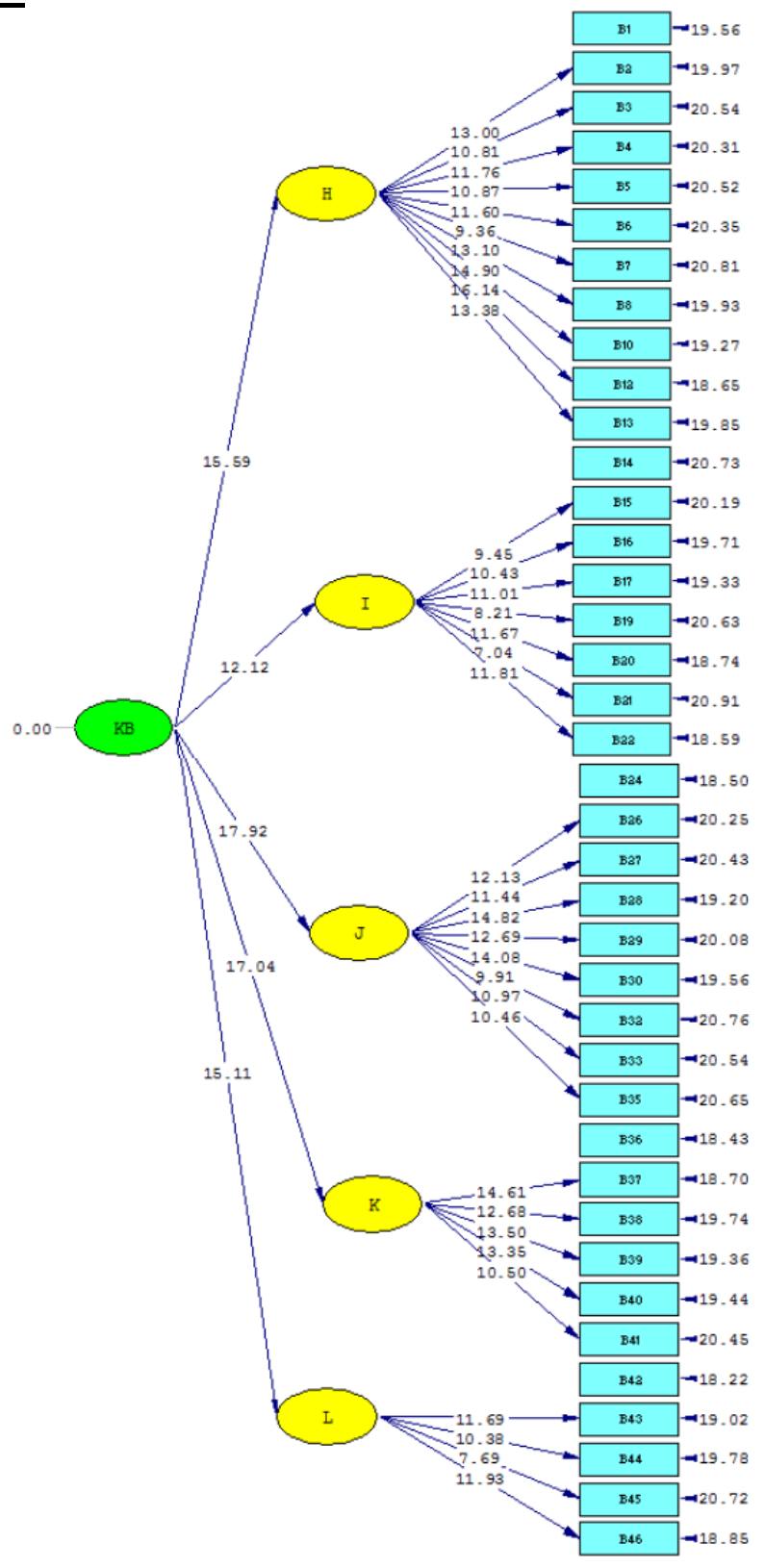

Gambar 2.3 Nilai t-values masing-masing indikator Analisis tahap II 
Pada gambar 1.3, tampak bahwa nilai t-hitung untuk masing-masing indicator H-L yaitu 15,59; 12,12; 17,92; 17,04; 15,11 berturut-turut. Nilai-nilai tersebut lebih besar dari nilai t-tabel pada taraf signifikansi $\alpha=0,05$ dan derajat bebas 927 (n-1) sebesar 1,960. Hal tersebut menunjukkan bahwa pengaruh masing-masing indicator tersebut terhadap KB signifikan.

Tabel 2.2.Statistic dan Criteria fit Model

\begin{tabular}{|c|c|c|c|c|}
\hline No. & Statistik & $\begin{array}{c}\text { Hasil } \\
\text { perhitungan }\end{array}$ & Kriteria 'fit" & Keterangan \\
\hline 1 & $\begin{array}{l}\text { Minimum fit function chi- } \\
\text { square }\left(\chi^{2}\right)\end{array}$ & $\begin{array}{l}2231.07 \\
(\mathrm{P}=0.0)\end{array}$ & $\mathrm{p}>0.05$ & Tdk fit \\
\hline 2 & RMSEA & 0.052 & $<0.08$ & Fit \\
\hline \multirow[t]{2}{*}{3} & $\begin{array}{l}\text { Root Mean Square Residual } \\
\text { (RMR) }\end{array}$ & 0.038 & $\leq 0,10$ & Fit \\
\hline & Standardized RMR & 0.060 & $\leq 0,10$ & Fit \\
\hline 4 & GFI & 0.88 & $\geq 0,90$ & Tdk fit \\
\hline 5 & AGFI & 0.86 & $0.80 \leq \mathrm{AGFI}<0,9$ & Marjinal fit \\
\hline 6 & NFI & 0.90 & $\geq 0,90$ & Fit \\
\hline 7 & NNFI & 0.93 & $\geq 0,90$ & Fit \\
\hline 8 & CFI & 0.93 & $\geq 0,90$ & Fit \\
\hline 9 & IFI & 0.93 & $\geq 0,90$ & Fit \\
\hline 10 & RFI & 0.90 & $\geq 0,90$ & Fit \\
\hline 11 & PNFI & 0.85 & $\begin{array}{l}\text { 0: tidak fit, semakin besar } \\
\text { semakin fit }\end{array}$ & Fit \\
\hline
\end{tabular}

Berdasarkan hasil analisis data diperoleh bahwa lebih banyak yang memenuhi criteria fit dibandingkan dengan yang tidak memenuhi yaitu 10 yang memenuhi criteria fit sedangkan hanya 2 yang tidak memenuhicriteria fit, sehingga model teoritis sesuai dengan data empiric (Fit). 


\section{Daftar pustaka}

Geldhof, Preacher, dan Zyphur. 2013. Reliability Estimation in a Multilevel Confirmatory Factor Analysis Framework. Journal of Psychological Methods 2014, Vol. 19, No. 1, 72-91. Diakses 14 Juni 2017 pada http://quantpsy.org/pubs/geldhof preacher zyphur 2014.pdf

Hair, J. F., Black, W. C., Babin, B. J., \& Anderson, R. E. (2010). Multivariate data analysis: A global perspective (seventh ed). New Jersey: Pearson Education, Inc.

Mansyur,. Rasyid, Harun,.\& Suratno. 2009. Assesmen Pembelajaran di Sekolah. Yogyakarta: Multi Pressindo.

Iskandar, A. (2011). PENELITIAN DAN EVALUASI PENDIDIKAN_ DICK \& CARRY, ADDIE, ASSURE, DAN PROGRAM. Retrieved from http://akbar-iskandar.blogspot.co.id/2011/12/dickcarry-addie-assure-dan-program.html 